\title{
Role of CITED2 in stem cells and cancer (Review)
}

\author{
BEIYING AN ${ }^{1}$, XUFENG JI $^{1}$ and YUBAO GONG ${ }^{2}$ \\ Departments of ${ }^{1}$ Clinical Laboratory and ${ }^{2}$ Orthopaedics, The First Hospital of Jilin University, \\ Changchun, Jilin 130021, P.R. China
}

Received April 28, 2020; Accepted July 22, 2020

DOI: 10.3892/ol.2020.11968

\begin{abstract}
Cbp/P300 interacting transactivator with Glu/Asp-rich carboxy-terminal domain 2 (CITED2) is a transcription co-factor that interacts with several other transcription factors and co-factors, and serves critical roles in fundamental cell processes, including proliferation, apoptosis, differentiation, migration and autophagy. The interacting transcription factors or co-factors of CITED2 include LIM homeobox 2, transcription factor AP-2, SMAD2/3, peroxisome proliferator-activated receptor $\gamma$, oestrogen receptor, MYC, Nucleolin and p300/CBP, which regulate downstream gene expression, and serve important roles in the aforementioned fundamental cell processes. Emerging evidence has demonstrated that CITED2 serves an essential role in embryonic and adult tissue stem cells, including hematopoietic stem cells and tendon-derived stem/progenitor cells. Additionally, CITED2 has been reported to function in different types of cancer. Although the functions of CITED2 in different tissues vary depending on the interaction partner, altered CITED2 expression or altered interactions with transcription factors or co-factors result in alterations of fundamental cell processes, and may affect stem cell maintenance or cancer cell survival. The aim of this review is to summarize the molecular mechanisms of CITED2 function and how it serves a role in stem cells and different types of cancer based on the currently available literature.
\end{abstract}

\section{Contents}

1. Introduction

2. Molecular mechanisms of CITED2 function

3. Function of CITED2 in stem cells

4. Function of CITED2 in cancer

5. Conclusion and future perspectives

Correspondence to: Dr Yubao Gong, Department of Orthopaedics, The First Hospital of Jilin University, 1 Xinmin Street, Changchun, Jilin 130021, P.R. China

E-mail: gongyb@jlu.edu.cn

Key words: CITED2, transcription factor, transcription co-factor, p300, stem cell, cancer

\section{Introduction}

Cancer is one of the leading causes of mortality worldwide, and has been the second highest cause of mortality in the USA in recent years $(1,2)$. Cancer is a group of diseases that is characterised by aberrant and uncontrolled growth of tissues or cells. The development of cancer is attributed to dysregulation of cell proliferation, apoptosis, differentiation, migration and autophagy (3). Transcription factors and their co-factors are the basic machinery controlling cell processes. Activity of several transcription factors is altered in a number of types of cancer through numerous and varying mechanisms, including chromosomal translocations, gene amplification or deletion, point mutations and dysregulated expression, and indirectly through non-coding DNA mutations that affect transcription factor binding $(4,5)$. These transcription factors are also considered candidate oncogenic genes. Furthermore, transcription co-factors alter the activity of transcription factors by interacting with them, serving critical roles in cancer (5).

$\mathrm{Cbp} / \mathrm{P} 300$ interacting transactivator with Glu/Asp-rich carboxy-terminal domain 2 (CITED2) is a protein encoded by the Cited 2 gene and is a transcription co-factor. The Cited 2 gene was cloned around two decades ago $(6,7)$, and was reported to promote the development of cancer when overexpressed in cells in vitro (7). CITED2 is essential for mouse embryonic development, as deletion of CITED2 results in embryonic lethality around embryonic day 10.5 (8). CITED2 is also essential for the development of the liver, lungs, heart, neural tube, left-right patterning and eye development (8-13). CITED2 modulates gene transcription by directly or indirectly interacting with transcription factors or co-factors without a DNA binding motif (14-22). Cited2-null mouse embryonic fibroblasts exhibited premature arrest of proliferation (senescence) (23), which suggests that CITED2 is essential for cell proliferation. Taken together, these findings demonstrated that CITED2 serves a critical role in several fundamental cellular processes.

In addition to the critical role of CITED2 in several fundamental cell processes, CITED2 has been reported to serve roles in numerous different types of cancer. For example, lung cancer (21), gastric cancer (24) and breast cancer $(19,25,26)$. Cancer stem cells (CSCs) are hypothesized to be a population of cells with multipotent stem cell-like properties, and can cause cancer relapse, metastasis, multidrug resistance and radiation resistance through their ability to arrest in the G0 phase, giving rise to new tumours when they finally leave 
cell-cycle arrest (27-29). CSCs exhibit strong self-renewal capacity, in a similar way to normal stem cells (30). As the function of CITED2 in CSCs has not been extensively studied, reviewing the function of CITED2 in stem cells may provide directions for future studies. In the present review, the molecular mechanisms of CITED2 function, and the role of CITED2 in stem cells and different types of cancer are discussed.

\section{Molecular mechanisms of CITED2 function}

CITED2 is a transcriptional co-regulator without a DNA binding domain, that can directly interact with a host of transcription factors and co-factors, including LIM homeobox 2, transcription factor AP-2 (TFAP2), SMAD2/3, peroxisome proliferator-activated receptor (PPAR)- $\gamma$, oestrogen receptor, MYC, Nucleolin and p300/CBP, thus regulating the ability of these binding partners to activate or inactivate gene transcription $(14-19,21,22)$. The molecular mechanism of CITED2 function varies based on the type of tissue and the binding partner. In this section, the molecular function of CITED2 in general is briefly summarized. The transcription factors interacting with CITED2 or regulated by CITED2 are listed in Table I. CITED2 was originally found to displace p300/CBP from hypoxia-inducible factor (HIF)-1 $\alpha$, thereby negatively regulating HIF-1 $\alpha$ function (14). HIF-1 $\alpha$ functions as a master regulator of cellular and systemic homeostatic response to hypoxia by activating transcription of a number of genes, including those involved in energy metabolism, angiogenesis, apoptosis, and other genes whose protein products increase oxygen delivery or facilitate metabolic adaptation to hypoxia (31). HIF-1 $\alpha$ also serves an important role in stem cells and cancer (32-34). The molecular mechanisms through which CITED2 interacts with p300/CBP to inhibit HIF-1 $\alpha$ function has been intensively studied (35-39). CITED2 acts as a bridge, directly interacting with and co-activating TFAP2 and the p300/CBP transcriptional co-activator complex to stimulate TFAP2-mediated transcriptional activation $(8,12,16,40,41)$. CITED2 positively regulates TGF- $\beta$ signalling through its association with the SMAD2/3-mediated transcriptional co-activator complex, and upregulates the expression of downstream targets, including matrix metalloproteinase (MMP)-9 and vascular endothelial growth factor (VEGF) $(18,42)$. CITED2 co-activates PPAR- $\alpha$ and PPAR- $\gamma$ transcriptional activities (17,43-45). CITED2 also functions as a transcriptional co-activator of the oestrogen receptor in breast cancer cells (19). Notably, CITED2 participates in sex determination and early gonad development through its combined action with WT1 and SF1, and regulates transcription activation of the genes located in the sex-determining region of the Y chromosome $(46,47)$. By regulating the Nodal-Pitx $2 \mathrm{c}$ pathway, CITED2 serves a role in controlling left-right gene transcription in the left lateral plate mesoderm (12,48-50). CITED2 is also reported to serve an essential role in the differentiation of the adrenal cortex from the adrenogonadal primordium, which stimulates WT1-mediated transcription activation, thereby increasing the promoter activity of the nuclear hormone receptor NR5A1 (47,51). CITED2 functions as a transcriptional co-repressor by interfering with the binding of HIF1- $\alpha$ or STAT2 with their transcription co-activator, p300/CBP $(9,35,36,52-54)$. By displacing p300 from binding with ETS-1, CITED2 was shown to co-repress expression of MMPs, including MMP-1 and MMP-13 (55). Through downregulation of MMP expression, CITED2 was revealed to exhibit a chondroprotective role and is considered a potential drug target for treatment of osteoarthritis $(56,57)$. A previous study demonstrated that by physically interacting with the DNA-binding transcription activator ISL1, CITED2 enhanced embryonic stem cell (ESC) cardiac differentiation (58). ISL1 has been shown to serve a role in several different types of cancer, including gastric cancer (59) and breast cancer $(60,61)$. Therefore, whether CITED2 serves a role in cancer through its interaction with ISL1 will require further investigation in future studies.

\section{Function of CITED2 in stem cells}

CITED2 is essential for differentiation of hematopoietic stem cells (HSC) in the foetal liver and adult bone marrow, as Cited2-null mice exhibit impaired HSC function in the foetal liver and adult bone marrow (62-64). In the foetal liver, expression of self-renewal and survival-associated genes in HSCs (including Bmi-1, Wnt5a, LEF-1, Notch-1 and GATA2) were revealed to be significantly downregulated in Cited 2 -null HSCs (62). Studies have further revealed that PU.1 co-operates with CITED2 to maintain HSC $(65,66)$. The role of CITED2 in hematopoietic stem cells has been previously reviewed (64). Thus, in the present review, a focus is placed on adult tissue stem cells, ESCs and induced pluripotent stem cells (iPSC).

Adult tissue stem cells: Tendon-derived stem/progenitor cells (TSPC) are the adult stem cells resident in the tendon tissue and are responsible for regeneration of tenocytes and healing of injuries to the tendons (67). A tendon's healing capacity is gradually reduced with age, which may be due to decreased CITED2 expression in aged TSPCs, which results in defective self-renewal and altered differentiation fates (68). The proliferation rate is decreased, cell cycle progression is delayed and cell fate patterns are also altered in aged TSPCs (68). In particular, expression of tendon lineage marker genes is decreased, while adipocytic differentiation is increased in aged TSPCs (68). Another study suggested that CITED2 prevented TGF- $\beta 2$-induced TSPC senescence through downregulation of SP1 and P21, and upregulation of Myc (69). Whether increasing CITED2 expression can restore proliferation, cell cycle progression and determination of differentiation fate in aged TSPC, or even enhance tendon healing in vivo remains to be determined and should be the focus of future studies.

Although Cited 2 is ubiquitously expressed (70) in other types of adult tissue stem cells, including adipose tissue-derived stem cells, intestinal stem cells, mammary stem cells and neural stem cells, whether CITED2 serves a role in the self-renewal and apoptosis of these cells remains to be determined.

ESCs: Interactions between transcription factors and transcription co-factors determine the fate of ESCs (71). Chromatin immunoprecipitation-seq analysis revealed that p300, a transcription co-factor, was mapped in the circuit of ESC stemness via its co-occupancy with stem cell marker transcription factor OCT4 on target genes (71). p300 is directly involved in regulating Nanog expression in mouse ESCs (72), 
Table I. Transcription factors interacting with CITED2 or regulated by CITED2.

\begin{tabular}{|c|c|c|c|}
\hline Transcription factor(s) & Association with CITED2 & Function & (Refs.) \\
\hline TFAP2 & Directly interacts with CITED2 & $\begin{array}{l}\text { Normal neural tube and cardiac development, } \\
\text { left-right patterning }\end{array}$ & $(8,12,16,40,41)$ \\
\hline SMAD2/3 & Directly interacts with CITED2 & $\begin{array}{l}\text { Upregulates TGF } \beta \text { downstream targets, } \\
\text { such as MMP9, VEGF }\end{array}$ & $(18,42)$ \\
\hline PPAR- $\alpha$, PPAR- $\gamma$ & Directly interacts with CITED2 & $\begin{array}{l}\text { Together with CITED2, participates in } \\
\text { signalling cascades of hypoxic response and } \\
\text { angiogenesis }\end{array}$ & $(17,43-45)$ \\
\hline WT1 & Directly interacts with CITED2 & $\begin{array}{l}\text { Regulates SF1 expression, sex determination } \\
\text { and early gonad development }\end{array}$ & $(46,47)$ \\
\hline Pitx2c & $\begin{array}{l}\text { CITED } 2 \text { with TFAP2 regulates } \\
\text { Pitx } 2 \text { c expression }\end{array}$ & Controls left-right gene transcription & $(12,48-50)$ \\
\hline HIF- $1 \alpha$ & CITED2 inhibits HIF-1a activity & $\begin{array}{l}\text { Displace p300/CBP from HIF-1 } \alpha \text { represses } \\
\text { HIF-1a downstream targets expression }\end{array}$ & $(14,35-39)$ \\
\hline ETS1 & CITED2 binds to ETS1 & $\begin{array}{l}\text { Displaces p300/CBP from ETS1, represses } \\
\text { MMP expression }\end{array}$ & $(55)$ \\
\hline ISL1 & Directly interacts with CITED2 & Promotes stem cells cardiac differentiation & $(58)$ \\
\hline Myc & Directly interacts with CITED2 & $\begin{array}{l}\text { Recruits p300 and Myc to E2F3 promoter and } \\
\text { transactivates E2F3 expression and increases } \\
\text { G1/S cell cycle progression }\end{array}$ & $(21)$ \\
\hline Nanog, Klf4, Tbx3 & $\begin{array}{l}\text { CITED } 2 \text { regulates Nanog, Klf4 } \\
\text { and Tbx } 3 \text { expression }\end{array}$ & ESC proliferation, survival and self-renewal & $(76)$ \\
\hline Nucleolin & $\begin{array}{l}\text { CITED2 regulates Nucleolin } \\
\text { expression }\end{array}$ & $\begin{array}{l}\text { By chaperone PRMT5 and p300 to Nucleolin } \\
\text { promoter, CITED2 activates Nucleolin } \\
\text { transcription, involved in prostate cancer } \\
\text { metastasis }\end{array}$ & $(22)$ \\
\hline
\end{tabular}

CITED2, Cbp/P300 interacting transactivator with Glu/Asp-rich carboxy-terminal domain 2; TFAP2, transcription factor AP-2; SMAD2/3, mothers against decapentaplegic homolog $2 / 3$; TGF $\beta$, transforming growth factor $\beta$; MMP9, matrix metallopeptidase 9; VEGF, vascular endothelial growth factor; PPAR $\alpha / \gamma$, peroxisome proliferator-activated receptor $\alpha / \gamma$; WT1, Wilms tumor 1 transcription factor; SF1, splicing factor 1; Pitx2c, paired like homeodomain 2C; HIF1a, hypoxia inducible factor 1 subunit $\alpha$; ETS1, avian erythroblastosis virus E26 (V-Ets) oncogene homolog-1; ISL1, ISL LIM homeobox 1; Myc, MYC proto-oncogene, BHLH Transcription Factor; Nanog, homeobox transcription factor Nanog; Klf4, Kruppel-like factor 4; Tbx3, T-Box transcription factor 3; ESC, embryonic stem cell; PRMT5, protein arginine methyltransferase 5 .

whereas CITED2 directly interacts with p300. By performing genome-wide screening of CITED2-overexpressing mouse ESCs, CITED2 was shown to be able to rescue the ESC phenotype following removal of leukaemia inhibitory factor (LIF) from the growth media (73). Loss-of-function of Cited 2 in mouse ESC does not affect ESC proliferation and does not alter the undifferentiated state of ESCs in the presence of LIF (74). However, knockout of Cited 2 delayed ESC differentiation due to delayed silencing of the genes involved in the maintenance of pluripotency and self-renewal of stem cells (including Oct4, Klf4, Sox 2 and $c-M y c$ ) (74). A recent study revealed that Cited2-depleted stem cells retain higher expression levels of pluripotency-related transcription factors, including Nanog and Klf4, and that loss of Cited 2 in differentiating ESCs delayed differentiation (75). However, Kranc et al (76) demonstrated that CITED2 is required for ESC proliferation, survival and self-renewal, by directly regulating the transcriptional expression of Nanog, Klf4 and Tbx3. Spontaneous differentiation of Cited2-knockdown
ESCs occurred through downregulation of stem cell markers (including Nanog, Oct4, Sox 2 and Tbx3), and upregulation of mesoderm gene markers (including Brachyury and $\mathrm{Cdx} 2$ ) and the ectoderm gene marker (Foxa2) (76). A possible explanation for the discrepancy between these previous studies is a result of the different methods of deleting the Cited 2 gene used in the ESCs. Li et al (74) used a sequential targeting method; deleting the floxed Cited 2 allele first by using Cag-cre, and then using a knockout targeting vector to delete the other allele. It is possible that the selected ESC clones were adapted to loss of Cited 2 and thus survived. In fact, Kranc et al (76) observed a small portion of ESCs $(\sim 3 \%)$ that were able to self-renew without CITED2. Perhaps this small portion of self-renewing ESCs may be used to elucidate the mechanisms of how ESCs survive and self-renew.

iPSCs: Generation of human iPSCs from somatic cells have increased the potential prospects of personalized medicine $(77,78)$. Four key transcription factors (Oct4, Sox2, Klf4 and c-Myc) comprise the key regulatory network of ESCs, and 
overexpression of these transcription factors in somatic cells give rise to pluripotent stem cells, or iPSCs $(79,80)$. As described earlier, CITED2 regulates expression of stem cell marker transcription factors. Charneca et al (81), assessed whether overexpression of Cited 2 alone was sufficient for generation of iPSCs. Notably, overexpression of Cited 2 in mouse embryonic fibroblasts did activate expression of certain stem cell marker transcription factors, including Nanog, Sox 2 and Rex 1, but this was not sufficient for generation of iPSCs (81). Furthermore, overexpression of CITED2 in the pre-senescent fibroblasts significantly increased the efficiency of iPSC generation using the combination of the four transcription factors that Yamanaka established (79-81). It has been reported that aged cells are more difficult to transform into iPSCs compared with younger cells $(82,83)$, and improving our understanding of the differences between aged and younger cells may highlight a possible solution for the generation of iPSCs from aged cells.

\section{Function of CITED2 in cancer}

Overexpression of Cited 2 in Rat 1 fibroblasts results in a loss of cell contact inhibition in in vitro cell cultures and in nude mice in vivo, highlighting the potential role of Cited 2 in the transformation of certain types of cells (7). A recent study used system-level approaches to analyse the genome-wide transcriptome of the protein-coding genes of 17 major types of cancer with respect to clinical outcome (84). This study revealed that Cited 2 was expressed in all 17 types of cancer, although it had low cancer specificity (proteinatlas.org/pathology) (84). A general pattern of shorter patient survival times was associated with upregulation of genes involved in cell growth (84). CITED2, a protein involved in cell growth and other fundamental cell processes, has been reported to serve a critical role in different types of cancer, which are further discussed below.

CITED2 in breast cancer. Breast cancer accounts for $30 \%$ of all cancer cases in females in the USA and is the leading cause of cancer-associated mortality worldwide (2). Cited2 expression was shown to be upregulated in primary breast cancer specimens and bone metastatic tumours compared with the normal mammary epithelium $(25,85)$. Notably, cell lines with bone metastatic capacity in animal models exhibit the highest expression levels of Cited 2 compared with less metastatic cell lines (25). A recent study also confirmed that human metastatic tumours express higher mRNA levels of Cited2 compared with primary tumours and normal epithelium (26). Additionally, expression levels of Cited2 are negatively associated with survival $(19,25)$. Cited 2 expression levels are associated with disease-free survival in patients with breast cancer, and has been proposed to serve as potential prognostic marker (85,86). However, van Agthoven et al (87) reported that Cited 2 mRNA expression levels were significantly increased in human breast cancer cell lines, and an analysis of data obtained from the Genomic Spatial Event database showed that Cited 2 levels are lower in breast cancer tissue compared with normal tissues, albeit not statistically significant (22). Despite the discrepancy between studies, CITED2 is able to modulate oestrogen receptor transcriptional activity in breast cancer cells, and thus, elevated Cited 2 expression may lead to oestrogen-independent oestrogen receptor activation, resulting in a reduction in oestrogen dependence and thus a reduced response to anti-oestrogen therapy (19). CITED2 may also modulate the capability of breast cancer metastases by positively regulating IKK $\alpha$ (26). Using breast cancer cell lines, it was demonstrated that knockdown of Cited2 expression resulted in reduced expression of the $\mathrm{NF}-\kappa \mathrm{B}$ signalling pathway regulator IKK $\alpha$, and of the NF- $x \mathrm{~B}$ signalling pathway downstream targets, OPN, MMP9, $\mu \mathrm{PA}$, SPARC, IL-11 and IL-1 $\beta$, which are known to serve roles in metastasis (26). Furthermore, knockdown of Cited 2 expression in breast cancer cell lines attenuates breast tumour growth in mice (42), further highlighting the role of CITED2 in breast cancer progression. Therefore, it was proposed that CITED2 regulated vascularization of breast tumours through TGF- $\beta$ dependent VEGF expression (42). Tumour-associated macrophages are important immune cells that serve a role in promoting primary tumour growth, metastatic progression, poor overall survival and therapeutic resistance (88-91). Notably, silencing Cited 2 expression in breast cancer cell lines decreased the expression of the macrophage chemoattractant, CCL20, and thus attenuated macrophage recruitment (92). In fast growing tumours, cells usually encounter hypoxic stress, which results in induction of HIF expression, and apoptosis can be induced by HIF (93). Bakker et al (94) reported that in MCF7 breast cancer cells, HIF-1 $\alpha$ induced FOXO3a expression and upregulated the downstream CITED2 expression. Increased expression of CITED2 inhibits HIF-1 $\alpha$-induced cell apoptosis (94). Although the mechanism of CITED2 function in breast cancer is not fully understood, the results of the aforementioned studies have demonstrated that CITED2 may be a potential therapeutic target for treatment of breast cancer.

Cited2 in leukaemia. CITED2 serves a critical role in the maintenance of hematopoietic stem cells $(63,64,66,95)$, and loss of Cited 2 in adult mice results in a loss of HSCs and bone marrow failure (63). Although leukaemia primarily rises from the hematopoietic progenitor level, different types of leukaemia have different causes (96). In acute myeloid leukaemia cells, Cited 2 regulates P53 activity by regulating the AKT signalling pathway at multiple levels (97). When Cited 2 expression was knocked down, expression of the AKT signalling pathway positive regulator transcription factor, SOX4, was decreased; however, expression of the negative regulator Thioredoxin-interacting protein was upregulated. Expression of the p53 target gene, PHLDA3, was downregulated, and expression of BCL2 gene was upregulated. As a consequence, loss of Cited2 expression in acute myeloid leukaemia cells increased P53-mediated apoptosis (97). Therefore, targeting Cited2 expression or CITED2 function may be a potential therapeutic method for treating patients with AML.

Cited2 in lung cancer. CITED2 is essential for foetal lung maturation in mice; Cited2-null lung exhibit reduced terminal sac space at embryonic day 18.5 (11). However, the function of CITED2 in lung cancer is not fully understood. Our unpublished preliminary data based on data mining from the Oncomine database (98) and data analysis using The Cancer Genome Atlas (22) all demonstrated that Cited2 expression levels in lung cancer are lower than in normal lung tissues from the same patients. The downregulation of Cited 2 expression in 
lung cancer may be explained by the lower expression of Foxa2 directly reducing Cited 2 expression (98). However, another study reported that higher expression of CITED2 in lung cancer was associated with a less favourable prognosis (21). The proposed molecular mechanism in lung cancer is: CITED2 enhances E2F3 transcription factor expression by interacting with Myc, leading to increased G1/S cell cycle progression. On the other hand, CITED2 enhances Myc-mediated suppression of p21(CIP1), inhibiting cellular quiescence (21). Notably, knockdown of CITED2 expression can sensitize lung cancer cells to chemotherapy (Cisplatin), primarily through stabilization of p53 (99). Therefore, CITED2 may potentially serve as a therapeutic target in the treatment of lung cancer. A recent data mining study further found that CITED2 expression is significantly different between lung cancer specimen from smokers and non-smokers, suggesting that CITED2 may be used as a biomarker for smoking-related lung cancer (100).

Cited 2 in prostate cancer. Prostate cancer is the most frequently diagnosed type of cancer in males, and the second leading cause of cancer-associated mortality among males (2). Despite the huge advances in prostate cancer therapy in recent years, the prognosis of patients with advanced prostate cancer remains generally poor due to metastasis (101), as the molecular and cellular mechanisms of prostate metastasis are not well understood. A recent study revealed that CITED2 is highly expressed in prostate cancer tissue from patients compared with normal tissues. Notably, metastatic prostate tumours express even higher CITED2 mRNA levels than non-metastatic prostate tumours (22). This study found that high CITED2 expression is significantly correlated with the overall survival of patients with prostate cancer. The authors further elucidated the mechanisms of this and proposed that CITED2 recruits Protein Arginine Methyltransferase 5 and p300 to nucleolin, which promotes epithelial-mesenchymal transition and prostate cancer metastasis (22). Therefore, CITED2 may be a potential therapeutic target for treatment of metastatic prostate cancer (22).

CITED2 in colon cancer. Colon cancer or colorectal cancer is the third most frequently diagnosed cancer type, in males and females (2). The function of CITED2 in colon cancer has not yet been extensively studied. One study using a colon cancer cell line reported that knockdown of Cited 2 increased cancer cell invasiveness in vitro by upregulating MMP-13 expression (102). The histone deacetylase (HDAC) inhibitor, butyrate, resulted in upregulated expression of Cited 2 in colon cancer cells and consequently downregulated MMP-13 expression. Ectopic expression of Cited 2 induced colon cancer cell growth arrest (102). RNA-seq analysis showed that Cited 2 expression was correlated with resistance to the chemotherapeutic reagent, irinotecan (103). The role of CITED2 in irinotecan resistance and the underlying mechanisms remain to be determined.

CITED2 in gastric cancer. Gastric cancer (colloquially referred to as stomach cancer) is a major category of cancer and is a leading cause of mortality in cancer-associated diseases (2). A few recent studies investigated the possible roles of CITED2 in gastric cancer. Data mining using existing gene expression data revealed that $C$ ited 2 was a signature prognostic gene among
Table II. Stomach cancer population characteristics $(\mathrm{n}=877)$.

\begin{tabular}{lc}
\hline Characteristic & Stomach cance \\
\hline Median age at diagnosis (range), years & $62(17-90)$ \\
Sex & \\
Male & $591(67.4)$ \\
Female & $286(32.6)$ \\
Tumor stage & \\
I & $452(521.5)$ \\
II & $103(11.7)$ \\
III & $187(21.3)$ \\
IV & $103(11.7)$ \\
NA & $32(3.6)$ \\
\hline
\end{tabular}

Source: www.proteinatlas.org. All data are presented as N (\%) unless stated otherwise.

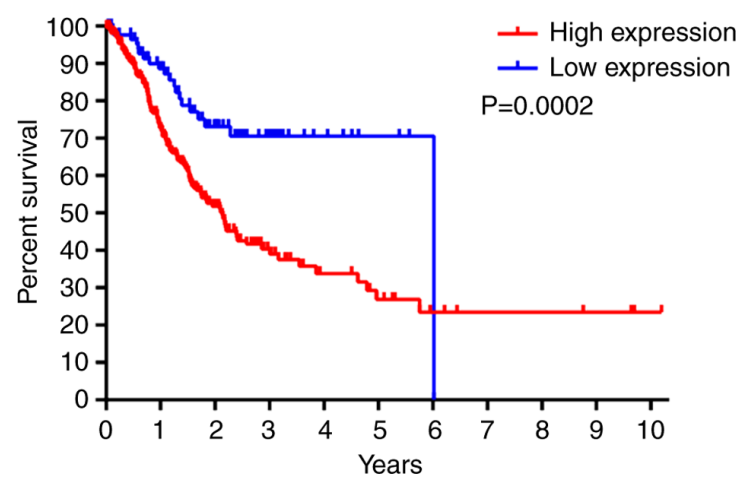

Figure 1. High CITED2 expression is associated with a poorer prognosis in stomach cancer. Data derived from www.proteinatlas.org.

16 genes (104). A Human Protein Atlas program used systems biology analysis and revealed that CITED2 is a prognostic predictor of stomach cancer (proteinatlas.org) (84). High expression of Cited 2 is associated with a worse prognosis in patients with stomach cancer (Fig. 1; patient information in Table II; data derived proteinatlas.org) (84). Notably, low expression of Cited 2 in gastric cancer cells is associated with chemoresistance (24). By overexpressing Cited 2 or inducing Cited 2 expression using an HDAC inhibitor in gastric cell lines, the cells were sensitized to the chemotherapeutic reagent, anthracycline, both in vitro and in vivo (24). There was also a small subset of patients with higher Cited 2 expression levels in gastric cancer with a more complete response to chemotherapy, including epirubicin, although the number of patients was too small to draw any conclusions from (24). One possible explanation for this is that usually, high expression levels of Cited 2 results in increased rates of cell proliferation and DNA synthesis, which in turn results in increased sensitivity to chemotherapy or radiotherapy. Mycophenolic acid (MPA), a metabolized product and active element of mycophenolate mofetil was revealed to inhibit gastric cancer cell invasion and migration (105). Based on microarray analysis, MPA may have downregulated the expression of a large number of pro-migratory genes and upregulated the expression of a number of anti-migratory genes, including Cited2 (105). 
An in vitro study by Tang et al (106) reported that knockdown of Cited 2 expression in gastric cells resulted in decreased cell proliferation, mitochondrial membrane potential and colony formation. Our understanding of the role of CITED2 in gastric cancer is limited and requires further study.

\section{Conclusion and future perspectives}

As CITED2 serves critical roles in numerous fundamental cell processes, it may be a suitable target for treatment of several types of cancer. Cited2-null normal tissue cells, including mouse embryonic fibroblast cells, HSCs, foetal liver cells, midbrain cells and neuroepithelium cells, exhibit premature senescence or an increase in the levels of apoptosis $(8,10,23,107,108)$. Although resistance to apoptosis is a hallmark of cancer cells, induction of senescence or apoptosis, is a hypothesized means of controlling cancer growth. Notably, several studies have reported that CITED2 inhibits P53 activation in cancer cells $(97,99,109,110)$, and upregulated expression of Cited 2 in cancer cells inhibits P53 activation and apoptosis. Therefore, targeting CITED2 by silencing Cited 2 gene expression and increasing cancer cell apoptosis $(99,106)$ may be a possible treatment for cancer. Knocking down CITED2 expression in lung cancer cells resulted in a shrinkage of tumour size in nude mice and increased host mouse survival rates (21). Other methods, including inducing expression of microRNAs targeting and downregulating Cited 2 expression, also results in apoptosis of cancer cells (111). Relapse and metastasis are the major hurdles of cancer therapy, and, whether CITED2 serves a role in cancer relapse or metastasis will be a topic of interest. As mentioned earlier, CITED2 directly or indirectly regulates expression of key stem cell transcription factors, OCT4, Nanog, Klf4 and Tbx3. These transcription factors are also known to be key players in cancer stem-like cells (112-115). Therefore, it is possible that CITED2 serves a key role in cancer stem cell function. Indirectly downregulating Cited 2 expression in chronic myeloid leukaemia using PPAR- $\gamma$ agonists resulted in an erosion of the leukaemia stem cell pool (116), which suggests that targeting CITED2 expression in cancer stem cell in general may be a therapeutic method for treatment of cancer, and preventing relapse. In conclusion, CITED2 is an essential transcription co-factor and may serve as a therapeutic target for the treatment of cancer.

\section{Acknowledgements}

Not applicable.

\section{Funding}

No funding was received.

\section{Availability of data and materials}

All datasets used and/or analyzed during the current study are available from the corresponding author on reasonable request.

\section{Authors' contributions}

YG conceived the presented idea and supervised the project. $\mathrm{BA}$ and XJ collected all the references and data. BA wrote the manuscript. All authors discussed, contributed toward and approved the final manuscript.

\section{Ethics approval and consent to participate}

This study does not contain any studies with human participants or animals performed by any of the authors.

\section{Patient consent for publication}

Not applicable.

\section{Competing interests}

The authors declare that they have no competing interests.

\section{References}

1. Siegel RL, Miller KD and Jemal A: Cancer statistics, 2018. CA Cancer J Clin 68: 7-30, 2018.

2. Siegel RL, Miller KD and Jemal A: Cancer statistics, 2019. CA Cancer J Clin 69: 7-34, 2019.

3. Lampe JW: Dairy products and cancer. J Am Coll Nutr 30 (5 Suppl 1): 464S-470S, 2011.

4. Lambert M, Jambon S, Depauw S and David-Cordonnier MH: Targeting transcription factors for cancer treatment. Molecules 23: 1479, 2018.

5. Bushweller JH: Targeting transcription factors in cancer-from undruggable to reality. Nat Rev Cancer 19: 611-624, 2019.

6. Shioda T, Fenner MH and Isselbacher KJ: MSG1 and its related protein MRG1 share a transcription activating domain. Gene 204: 235-241, 1997.

7. Sun HB, Zhu YX, Yin T, Sledge G and Yang YC: MRG1, the product of a melanocyte-specific gene related gene, is a cytokine-inducible transcription factor with transformation activity. Proc Natl Acad Sci USA 95: 13555-13560, 1998.

8. Bamforth SD, Braganca J, Eloranta JJ, Murdoch JN, Marques FI, Kranc KR, Farza H, Henderson DJ, Hurst HC and Bhattacharya S: Cardiac malformations, adrenal agenesis, neural crest defects and exencephaly in mice lacking Cited2, a new Tfap2 co-activator. Nat Genet 29: 469-474, 2001.

9. Yin Z, Haynie J, Yang X, Han B, Kiatchoosakun S, Restivo J, Yuan S, Prabhakar NR, Herrup K, Conlon RA, et al: The essential role of Cited2, a negative regulator for HIF-1alpha, in heart development and neurulation. Proc Natl Acad Sci USA 99: 10488-10493, 2002.

10. Qu X, Lam E, Doughman YQ, Chen Y, Chou YT, Lam M, Turakhia M, Dunwoodie SL, Watanabe M, Xu B, et al: Cited2, a coactivator of HNF4alpha, is essential for liver development. EMBO J 26: 4445-4456, 2007.

11. Xu B, Qu X, Gu S, Doughman YQ, Watanabe M, Dunwoodie SL and Yang YC: Cited2 is required for fetal lung maturation. Dev Biol 317: 95-105, 2008.

12. Bamforth SD, Braganca J, Farthing CR, Schneider JE, Broadbent C, Michell AC, Clarke K, Neubauer S, Norris D, Brown NA, et al: Cited 2 controls left-right patterning and heart development through a Nodal-Pitx2c pathway. Nat Genet 36: 1189-1196, 2004.

13. Huang TQ, Wang Y,Ebrahem Q, Chen Y,Cheng C, Doughman YQ, Watanabe M, Dunwoodie SL and Yang YC: Deletion of HIF-1a partially rescues the abnormal hyaloid vascular system in Cited2 conditional knockout mouse eyes. Mol Vis 18: 1260-1270, 2012.

14. Bhattacharya S, Michels CL, Leung MK, Arany ZP, Kung AL and Livingston DM: Functional role of p35srj, a novel p300/CBP binding protein, during transactivation by HIF-1. Genes Dev 13: 64-75, 1999.

15. Glenn DJ and Maurer RA: MRG1 binds to the LIM domain of Lhx2 and may function as a coactivator to stimulate glycoprotein hormone alpha-subunit gene expression. J Biol Chem 274: 36159-36167, 1999.

16. Bragança J, Eloranta JJ, Bamforth SD, Ibbitt JC, Hurst HC and Bhattacharya S: Physical and functional interactions among AP-2 transcription factors, p300/CREB-binding protein, and CITED2. J Biol Chem 278: 16021-16029, 2003. 
17. Tien ES, Davis JW and Vanden Heuvel JP: Identification of the CREB-binding protein/p300-interacting protein CITED2 as a peroxisome proliferator-activated receptor alpha coregulator. J Biol Chem 279: 24053-24063, 2004.

18. Chou YT, Wang H, Chen Y, Danielpour D and Yang YC: Cited2 modulates TGF-beta-mediated upregulation of MMP9. Oncogene 25: 5547-5560, 2006.

19. Lau WM, Doucet M, Huang D, Weber KL and Kominsky SL: CITED2 modulates estrogen receptor transcriptional activity in breast cancer cells. Biochem Biophys Res Commun 437: 261-266, 2013.

20. Fujita M, Takasaki T, Nakajima N, Kawano T, Shimura Y and Sakamoto H: MRG-1, a mortality factor-related chromodomain protein, is required maternally for primordial germ cells to initiate mitotic proliferation in C. Elegans. Mech Dev 114: 61-69, 2002.

21. Chou YT, Hsieh CH, Chiou SH, Hsu CF, Kao YR, Lee CC, Chung $\mathrm{CH}$, Wang $\mathrm{YH}$, Hsu HS, Pang ST, et al: CITED2 functions as a molecular switch of cytokine-induced proliferation and quiescence. Cell Death Differ 19: 2015-2028, 2012.

22. Shin SH, Lee GY, Lee M, Kang J, Shin HW, Chun YS and Park JW: Aberrant expression of CITED2 promotes prostate cancer metastasis by activating the nucleolin-AKT pathway. Nat Commun 9: 4113, 2018

23. Kranc KR, Bamforth SD, Braganca J, Norbury C, van Lohuizen $M$ and Bhattacharya S: Transcriptional coactivator Cited 2 induces Bmil and Mel18 and controls fibroblast proliferation via Ink4a/ARF. Mol Cell Biol 23: 7658-7666, 2003.

24. Regel I, Merkl L, Friedrich T, Burgermeister E, Zimmermann W, Einwächter H, Herrmann K, Langer R, Röcken C, Hofheinz R, et al: Pan-histone deacetylase inhibitor panobinostat sensitizes gastric cancer cells to anthracyclines via induction of CITED2. Gastroenterology 143: 99-109.e10, 2012.

25. Lau WM, Weber KL, Doucet M, Chou YT, Brady K, Kowalski J, Tsai HL, Yang J and Kominsky SL: Identification of prospective factors promoting osteotropism in breast cancer: A potential role for CITED2. Int J Cancer 126: 876-884, 2010.

26. Jayaraman S, Doucet M, Lau WM and Kominsky SL: CITED2 modulates breast cancer metastatic ability through effects on IKK $\alpha$. Mol Cancer Res 14: 730-739, 2016.

27. Reya T, Morrison SJ, Clarke MF and Weissman IL: Stem cells, cancer, and cancer stem cells. Nature 414: 105-111, 2001.

28. Chen W, Dong J, Haiech J, Kilhoffer MC and Zeniou M: Cancer stem cell quiescence and plasticity as major challenges in cancer therapy. Stem Cells Int 2016: 1740936, 2016.

29. Yang L, Shi P, Zhao G, Xu J, Peng W, Zhang J, Zhang G, Wang X, Dong Z, Chen F and Cui H: Targeting cancer stem cell pathways for cancer therapy. Signal Transduct Target Ther 5: 8, 2020 .

30. Bjerkvig R, Tysnes BB, Aboody KS, Najbauer J and Terzis AJ: Opinion: The origin of the cancer stem cell: Current controversies and new insights. Nat Rev Cancer 5: 899-904, 2005.

31. Pugh CW: Modulation of the hypoxic response. Adv Exp Med Biol 903: 259-271, 2016.

32. Gezer D, Vukovic M, Soga T, Pollard PJ and Kranc KR: Concise review: genetic dissection of hypoxia signaling pathways in normal and leukemic stem cells. Stem Cells 32: 1390-1397, 2014

33. Du J and Yang YC: HIF-1 and its antagonist Cited2: Regulators of HSC quiescence. Cell Cycle 11: 2413-2414, 2012

34. Henze AT and Acker T: Feedback regulators of hypoxia-inducible factors and their role in cancer biology. Cell Cycle 9: 2749-2763, 2010.

35. De Guzman RN, Martinez-Yamout MA, Dyson HJ and Wright PE: Interaction of the TAZ1 domain of the CREB-binding protein with the activation domain of CITED2: Regulation by competition between intrinsically unstructured ligands for non-identical binding sites. J Biol Chem 279: 3042-3049, 2004.

36. Matt T, Martinez-Yamout MA, Dyson HJ and Wright PE: The $\mathrm{CBP} / \mathrm{p} 300$ TAZ1 domain in its native state is not a binding partner of MDM2. Biochem J 381: 685-691, 2004.

37. Yoon H, Lim JH, Cho CH, Huang LE and Park JW: CITED2 controls the hypoxic signaling by snatching p300 from the two distinct activation domains of HIF-1 $\alpha$. Biochim Biophys Acta 1813: 2008-2016, 2011.

38. Berlow RB, Martinez-Yamout MA, Dyson HJ and Wright PE: Role of backbone dynamics in modulating the interactions of disordered ligands with the TAZ1 domain of the CREB-binding protein. Biochemistry 58: 1354-1362, 2019.

39. Ruiz-Ortiz I and De Sancho D: Competitive binding of HIF-1a and CITED2 to the TAZ1 domain of CBP from molecular simulations. Phys Chem Chem Phys 22: 8118-8127, 2020.
40. Chen CM, Bentham J, Cosgrove C, Braganca J, Cuenda A, Bamforth SD, Schneider JE, Watkins H, Keavney B, Davies B and Bhattacharya S: Functional significance of SRJ domain mutations in CITED2. PLoS One 7: e46256, 2012.

41. MacDonald ST, Bamforth SD, Braganca J, Chen CM, Broadbent C, Schneider JE, Schwartz RJ and Bhattacharya S: A cell-autonomous role of Cited 2 in controlling myocardial and coronary vascular development. Eur Heart J 34: 2557-2565, 2013.

42. Jayaraman S, Doucet M and Kominsky SL: Down-regulation of CITED2 attenuates breast tumor growth, vessel formation and TGF- $\beta$-induced expression of VEGFA. Oncotarget 8: 6169-6178, 2017.

43. Gonzalez YR, Zhang Y, Behzadpoor D, Cregan S, Bamforth S, Slack RS and Park DS: CITED2 signals through peroxisome proliferator-activated receptor-gamma to regulate death of cortical neurons after DNA damage. J Neurosci 28: 5559-5569, 2008.

44. Kim GD, Das R, Rao X, Zhong J, Deiuliis JA, Ramirez-Bergeron DL, Rajagopalan S and Mahabeleshwar GH: CITED2 restrains proinflammatory macrophage activation and response. Mol Cell Biol 38: e00452-17, 2018.

45. Liu Z, Wang Y, Dou C, Sun L, Li Q, Wang L, Xu Q, Yang W, Liu Q and Tu K: MicroRNA-1468 promotes tumor progression by activating PPAR- $\gamma$-mediated AKT signaling in human hepatocellular carcinoma. J Exp Clin Cancer Res 37: 49, 2018

46. Buaas FW, Val P and Swain A: The transcription co-factor CITED2 functions during sex determination and early gonad development. Hum Mol Genet 18: 2989-3001, 2009.

47. Val P, Martinez-Barbera JP and Swain A: Adrenal development is initiated by Cited 2 and $\mathrm{Wt} 1$ through modulation of Sf-1 dosage. Development 134: 2349-2358, 2007.

48. Weninger WJ, Lopes Floro K, Bennett MB, Withington SL, Preis JI, Barbera JP, Mohun TJ and Dunwoodie SL: Cited2 is required both for heart morphogenesis and establishment of the left-right axis in mouse development. Development 132: 1337-1348, 2005

49. Bentham J, Michell AC, Lockstone H, Andrew D, Schneider JE, Brown NA and Bhattacharya S: Maternal high-fat diet interacts with embryonic Cited 2 genotype to reduce Pitx $2 \mathrm{c}$ expression and enhance penetrance of left-right patterning defects. Hum Mol Genet 19: 3394-3401, 2010

50. Lopes Floro K, Artap ST, Preis JI, Fatkin D, Chapman G, Furtado MB, Harvey RP, Hamada H, Sparrow DB and Dunwoodie SL: Loss of Cited2 causes congenital heart disease by perturbing left-right patterning of the body axis. Hum Mol Genet 20: 1097-1110, 2011.

51. Combes AN, Spiller CM,Harley VR, Sinclair AH,Dunwoodie SL, Wilhelm D and Koopman P: Gonadal defects in Cited2-mutant mice indicate a role for SF1 in both testis and ovary differentiation. Int J Dev Biol 54: 683-689, 2010.

52. Berlow RB, Dyson HJ and Wright PE: Hypersensitive termination of the hypoxic response by a disordered protein switch. Nature 543: 447-451, 2017.

53. Shin DH, Li SH, Chun YS, Huang LE, Kim MS and Park JW: CITED2 mediates the paradoxical responses of HIF-1alpha to proteasome inhibition. Oncogene 27: 1939-1944, 2008.

54. Freedman SJ, Sun ZY, Kung AL, France DS, Wagner G and Eck MJ: Structural basis for negative regulation of hypoxiainducible factor-1alpha by CITED2. Nat Struct Biol 10: 504-512, 2003.

55. Yokota H, Goldring MB and Sun HB: CITED2-mediated regulation of MMP-1 and MMP-13 in human chondrocytes under flow shear. J Biol Chem 278: 47275-47280, 2003.

56. He Z, Leong DJ, Zhuo Z, Majeska RJ, Cardoso L, Spray DC, Goldring MB, Cobelli NJ and Sun HB: Strain-induced mechanotransduction through primary cilia, extracellular ATP, purinergic calcium signaling, and ERK1/2 transactivates CITED2 and downregulates MMP-1 and MMP-13 gene expression in chondrocytes. Osteoarthritis Cartilage 24: 892-901, 2016.

57. He Z, Leong DJ, Xu L, Hardin JA, Majeska RJ, Schaffler MB, Thi MM, Yang L, Goldring MB, Cobelli NJ and Sun HB: CITED2 mediates the cross-talk between mechanical loading and IL-4 to promote chondroprotection. Ann N Y Acad Sci 1442: 128-137, 2019.

58. Pacheco-Leyva I, Matias AC, Oliveira DV, Santos JM, Nascimento R, Guerreiro E, Michell AC, van De Vrugt AM, Machado-Oliveira G, Ferreira G, et al: CITED2 cooperates with ISL1 and promotes cardiac differentiation of mouse embryonic stem cells. Stem Cell Reports 7: 1037-1049, 2016. 
59. Guo T, Wen XZ, Li ZY, Han HB, Zhang CG, Bai YH, Xing XF, Cheng XJ, Du H, Hu Y, et al: ISL1 predicts poor outcomes for patients with gastric cancer and drives tumor progression through binding to the ZEB1 promoter together with SETD7. Cell Death Dis 10: $33,2019$.

60. Zhang Y, Wang L, Gao P, Sun Z, Li N, Lu Y, Shen J, Sun J, Yang Y, Dai $\mathrm{H}$ and Cai $\mathrm{H}$ : ISL1 promotes cancer progression and inhibits cisplatin sensitivity in triple-negative breast cancer cells. Int J Mol Med 42: 2343-2352, 2018

61. Li L, Sun F, Chen X and Zhang M: ISL1 is upregulated in breast cancer and promotes cell proliferation, invasion, and angiogenesis. Onco Targets Ther 11: 781-789, 2018.

62. Chen Y, Haviernik P, Bunting KD and Yang YC: Cited 2 is required for normal hematopoiesis in the murine fetal liver. Blood 110: 2889-2898, 2007.

63. Kranc KR, Schepers H, Rodrigues NP, Bamforth S, Villadsen E, Ferry H, Bouriez-Jones T, Sigvardsson M, Bhattacharya S, Jacobsen SE and Enver T: Cited2 is an essential regulator of adult hematopoietic stem cells. Cell Stem Cell 5: 659-665, 2009

64. Du J and Yang YC: Cited2 in hematopoietic stem cell function. Curr Opin Hematol 20: 301-307, 2013.

65. Korthuis PM, Berger G, Bakker B, Rozenveld-Geugien M, Jaques J, de Haan G, Schuringa JJ, Vellenga E and Schepers H: CITED2-mediated human hematopoietic stem cell maintenance is critical for acute myeloid leukemia. Leukemia 29: 625-635, 2015.

66. Mattes K, Geugien M, Korthuis PM, Brouwers-Vos AZ Fehrmann RSN, Todorova TI, Steidl U, Vellenga E and Schepers H: Transcriptional regulators CITED2 and PU.1 cooperate in maintaining hematopoietic stem cells. Exp Hematol 73: 38-49.e7, 2019

67. Bi Y, Ehirchiou D, Kilts TM, Inkson CA, Embree MC, Sonoyama W, Li L, Leet AI, Seo BM,Zhang L, et al: Identification of tendon stem/progenitor cells and the role of the extracellular matrix in their niche. Nat Med 13: 1219-1227, 2007.

68. Zhou Z, Akinbiyi T, Xu L, Ramcharan M, Leong DJ, Ros SJ, Colvin AC, Schaffler MB, Majeska RJ, Flatow EL and Sun HB: Tendon-derived stem/progenitor cell aging: Defective self-renewal and altered fate. Aging Cell 9: 911-915, 2010.

69. Hu C, Zhang Y, Tang K, Luo Y, Liu Y and Chen W: Downregulation of CITED2 contributes to TGF $\beta$-mediated senescence of tendon-derived stem cells. Cell Tissue Res 368 93-104, 2017

70. AlAbdi L, He M, Yang Q, Norvil AB and Gowher H: The transcription factor Vezf1 represses the expression of the antiangiogenic factor Cited 2 in endothelial cells. J Biol Chem 293 11109-11118, 2018

71. Chen X, Xu H, Yuan P, Fang F, Huss M, Vega VB, Wong E, Orlov YL, Zhang W, Jiang J, et al: Integration of external signaling pathways with the core transcriptional network in embryonic stem cells. Cell 133: 1106-1117, 2008

72. Zhong $\mathrm{X}$ and Jin Y: Critical roles of coactivator $\mathrm{p} 300$ in mouse embryonic stem cell differentiation and Nanog expression. J Biol Chem 284: 9168-9175, 2009.

73. Pritsker M, Ford NR, Jenq HT and Lemischka IR: Genomewide gain-of-function genetic screen identifies functionally active genes in mouse embryonic stem cells. Proc Natl Acad Sci USA 103: 6946-6951, 2006.

74. Li Q, Ramirez-Bergeron DL, Dunwoodie SL and Yang YC: Cited 2 gene controls pluripotency and cardiomyocyte differentiation of murine embryonic stem cells through Oct4 gene. J Biol Chem 287: 29088-29100, 2012.

75. Santos JMA, Mendes-Silva L, Afonso V, Martins G, Machado RSR, Lopes JA, Cancela L, Futschik ME, Sachinidis A, Gavaia P and Braganca J: Exogenous WNT5A and WNT11 proteins rescue CITED2 dysfunction in mouse embryonic stem cells and zebrafish morphants. Cell Death Dis 10: 582, 2019.

76. Kranc KR, Oliveira DV, Armesilla-Diaz A, Pacheco-Leyva I, Catarina Matias A, Luisa Escapa A, Subramani C, Wheadon H, Trindade M, Nichols J, et al: Acute loss of Cited2 impairs Nanog expression and decreases self-renewal of mouse embryonic stem cells. Stem Cells 33: 699-712, 2015.

77. Fakunle ES: iPSCs for personalized medicine: What will it take for Africa? Trends Mol Med 18: 695-699, 2012.

78. Gurwitz D: Human iPSC-derived neurons and lymphoblastoid cells for personalized medicine research in neuropsychiatric disorders. Dialogues Clin Neurosci 18: 267-276, 2016.
79. Takahashi K and Yamanaka S: Induction of pluripotent stem cells from mouse embryonic and adult fibroblast cultures by defined factors. Cell 126: 663-676, 2006

80. Takahashi K, Okita K, Nakagawa M and Yamanaka S: Induction of pluripotent stem cells from fibroblast cultures. Nat Protoc 2 : 3081-3089, 2007.

81. Charneca J, Matias AC, Escapa AL, Fernandes C, Alves A, Santos JMA, Nascimento R and Bragança J: Ectopic expression of CITED2 prior to reprogramming, promotes and homogenises the conversion of somatic cells into induced pluripotent stem cells. Exp Cell Res 358: 290-300, 2017.

82. Li H, Collado M, Villasante A, Strati K, Ortega S, Cañamero M, Blasco MA and Serrano M: The Ink4/Arf locus is a barrier for iPS cell reprogramming. Nature 460: 1136-1139, 2009.

83. Mahmoudi S and Brunet A: Aging and reprogramming: A two-way street. Curr Opin Cell Biol 24: 744-756, 2012.

84. Uhlen M, Zhang C, Lee S, Sjöstedt E, Fagerberg L, Bidkhori G, Benfeitas R, Arif M, Liu Z, Edfors F, et al: A pathology atlas of the human cancer transcriptome. Science 357: eaan2507, 2017.

85. Minemura H, Takagi K, Sato A, Takahashi H, Miki Y, Shibahara Y, Watanabe M, Ishida T, Sasano H and Suzuki T: CITED2 in breast carcinoma as a potent prognostic predictor associated with proliferation, migration and chemoresistance. Cancer Sci 107: 1898-1908, 2016.

86. Yang X, Vasudevan P, Parekh V, Penev A and Cunningham JM: Bridging cancer biology with the clinic: Relative expression of a GRHL2-mediated gene-set pair predicts breast cancer metastasis. PLoS One 8: e56195, 2013.

87. van Agthoven T, Sieuwerts AM, Veldscholte J, Meijer-van Gelder ME, Smid M, Brinkman A, den Dekker AT, Leroy IM van Ijcken WF, Sleijfer S, et al: CITED2 and NCOR2 in anti-oestrogen resistance and progression of breast cancer. $\mathrm{Br} J$ Cancer 101: 1824-1832, 2009.

88. De Palma M and Lewis CE: Cancer: Macrophages limit chemotherapy. Nature 472: 303-304, 2011.

89. Nielsen SR and Schmid MC: Macrophages as key drivers of cancer progression and metastasis. Mediators Inflamm 2017: 9624760,2017

90. Pollard JW: Tumour-educated macrophages promote tumour progression and metastasis. Nat Rev Cancer 4: 71-78, 2004.

91. Ruffell B and Coussens LM: Macrophages and therapeutic resistance in cancer. Cancer Cell 27: 462-472, 2015.

92. Jayaraman S, Doucet M and Kominsky SL: CITED2 attenuates macrophage recruitment concordant with the downregulation of CCL20 in breast cancer cells. Oncol Lett 15: 871-878, 2018.

93. Greijer AE and van der Wall E: The role of hypoxia inducible factor 1 (HIF-1) in hypoxia induced apoptosis. J Clin Pathol 57: 1009-1014, 2004

94. Bakker WJ, Harris IS and Mak TW: FOXO3a is activated in response to hypoxic stress and inhibits HIF1-induced apoptosis via regulation of CITED2. Mol Cell 28: 941-953, 2007.

95. Du J, Li Q, Tang F, Puchowitz MA, Fujioka H, Dunwoodie SL, Danielpour D and Yang YC: Cited 2 is required for the maintenance of glycolytic metabolism in adult hematopoietic stem cells. Stem Cells Dev 23: 83-94, 2014.

96. Deschler B and Lübbert M: Acute myeloid leukemia: Epidemiology and etiology. Cancer 107: 2099-2107, 2006.

97. Mattes K, Berger G, Geugien M, Vellenga E and Schepers H CITED2 affects leukemic cell survival by interfering with p53 activation. Cell Death Dis 8: e3132, 2017.

98. Jang SM, An JH, Kim CH, Kim JW and Choi KH: Transcription factor FOXA2-centered transcriptional regulation network in non-small cell lung cancer. Biochem Biophys Res Commun 463 961-967, 2015.

99. Wu ZZ, Sun NK and Chao CC: Knockdown of CITED2 using short-hairpin RNA sensitizes cancer cells to cisplatin through stabilization of p53 and enhancement of p53-dependent apoptosis. J Cell Physiol 226: 2415-2428, 2011.

100. Yao Y, Zhang T, Qi L, Liu R, Liu G, Wang X, Li J, Li J and Sun C: Competitive endogenous RNA network construction and comparison of lung squamous cell carcinoma in smokers and nonsmokers. Dis Markers 2019: 5292787, 2019.

101. Attard G and Antonarakis ES: Prostate cancer: AR aberrations and resistance to abiraterone or enzalutamide. Nat Rev Urol 13 697-698, 2016

102. Bai L and Merchant JL: A role for CITED2, a CBP/p300 interacting protein, in colon cancer cell invasion. FEBS Lett 581: 5904-5910, 2007. 
103. Li XX, Zheng HT, Peng JJ, Huang LY, Shi DB, Liang L and Cai SJ: RNA-seq reveals determinants for irinotecan sensitivity/resistance in colorectal cancer cell lines. Int J Clin Exp Pathol 7: 2729-2736, 2014.

104. Zhao X, Cai H, Wang X and Ma L: Discovery of signature genes in gastric cancer associated with prognosis. Neoplasma 63: 239-245, 2016.

105. Dun B, Sharma A, Teng Y, Liu H, Purohit S, Xu H, Zeng L and She JX: Mycophenolic acid inhibits migration and invasion of gastric cancer cells via multiple molecular pathways. PLoS One 8: e81702, 2013.

106. Tang Z, He G, Xu J and Zhongfu L: Knockdown of $\mathrm{Cbp} / \mathrm{P} 300$-interacting transactivator with Glu/Asp-rich carboxy-terminal domain 2 inhibits cell division and increases apoptosis in gastric cancer. J Surg Res 211: 1-7, 2017.

107. Barbera JP, Rodriguez TA, Greene ND, Weninger WJ, Simeone A, Copp AJ, Beddington RS and Dunwoodie S: Folic acid prevents exencephaly in Cited 2 deficient mice. Hum Mol Genet 11: 283-293, 2002.

108. Du J, Chen Y, Li Q, Han X, Cheng C, Wang Z, Danielpour D, Dunwoodie SL, Bunting KD and Yang YC: HIF-1 $\alpha$ deletion partially rescues defects of hematopoietic stem cell quiescence caused by Cited2 deficiency. Blood 119: 2789-2798, 2012.

109. Liu YC, Chang PY and Chao CC: CITED2 silencing sensitizes cancer cells to cisplatin by inhibiting p53 trans-activation and chromatin relaxation on the ERCC1 DNA repair gene. Nucleic Acids Res 43: 10760-10781, 2015.

110. Yoshida T, Sekine T, Aisaki K, Mikami T, Kanno J and Okayasu I: CITED2 is activated in ulcerative colitis and induces p53-dependent apoptosis in response to butyric acid. J Gastroenterol 46: 339-349, 2011.
111. Jiang Y, Zhou Z, Fei R, Zhou X, Wang J, Tao Y, Li J and Chen T: Role of miR-182-5p overexpression in trichloroethylene-induced abnormal cell cycle functions in human HepG2 cells. J Toxicol Environ Health A 82: 920-927, 2019.

112. Rasti A, Mehrazma M, Madjd Z, Abolhasani M, Saeednejad Zanjani L and Asgari M: Co-expression of cancer stem cell markers OCT4 and NANOG predicts poor prognosis in renal cell carcinomas. Sci Rep 8: 11739, 2018.

113. Ponti D, Costa A, Zaffaroni N, Pratesi G, Petrangolini G, Coradini D, Pilotti S, Pierotti MA and Daidone MG: Isolation and in vitro propagation of tumorigenic breast cancer cells with stem/progenitor cell properties. Cancer Res 65: 5506-5511, 2005.

114. Jeter CR, Yang T, Wang J, Chao HP and Tang DG: Concise review: NANOG in cancer stem cells and tumor development: An update and outstanding questions. Stem Cells 33: 2381-2390, 2015.

115. Yu F, Li J, Chen H, Fu J, Ray S, Huang S, Zheng H and Ai W: Kruppel-like factor 4 (KLF4) is required for maintenance of breast cancer stem cells and for cell migration and invasion. Oncogene 30: 2161-2172, 2011

116. Prost S, Relouzat F, Spentchian M, Ouzegdouh Y, Saliba J, Massonnet G, Beressi JP, Verhoeyen E, Raggueneau V, Maneglier B, et al: Erosion of the chronic myeloid leukaemia stem cell pool by PPAR $\gamma$ agonists. Nature 525: 380-383, 2015.

This work is licensed under a Creative Commons Attribution-NonCommercial-NoDerivatives 4.0 International (CC BY-NC-ND 4.0) License. 